\title{
A Point Mutation in the FRNK Motif of the Potyvirus Helper Component-Protease Gene Alters Symptom Expression in Cucurbits and Elicits Protection Against the Severe Homologous Virus
}

\author{
Amit Gal-On \\ Department of Virology, Agricultural Research Organization, the Volcani Center, P.O. Box 6, Bet Dagan 50-250, Israel. \\ Accepted for publication 17 January 2000.
}

\section{ABSTRACT}

Gal-On, A. 2000. A point mutation in the FRNK motif of the potyvirus helper component-protease gene alters symptom expression in cucurbits and elicits protection against the severe homologous virus. Phytopathology 90:467-473.

Sequence comparison had previously shown three amino acid changes in conserved motifs in the 455-amino acid sequence of the helper component-protease (HC-Pro) between a severe field strain of Zucchini yellow mosaic virus (ZYMV-NAT) and a mild field strain of ZYMV (ZYMV-WK). In this study, exchange of fragments and site-directed mutagenesis within the HC-Pro gene in an infectious clone of ZYMV enabled the effects of the mutations on symptom expression to be mapped. The substitution of Ile for Arg at position 180 in the conserved motif Phe-Arg-Asn-Lys (FRNK) of potyviruses was found to affect symptom expression. Infection of cucurbits with the engineered ZYMV (ZYMV-AG) that contained this mutation caused a dramatic symptom change from severe to mild in squash and to a symptom-free appearance in cucumber, melon, and watermelon. The Ile to Arg mutation was found to be stable, and no revertant virus was found after several passages through plants after long incubation periods. The AG strain was detected 4 days postinoculation and accumulated in cucurbits to a level and with kinetics similar to that of the wild-type ZYMV-AT strain. Cucurbit plants infected with the AG strain were protected against infection by the severe strain.
The potyvirus Zucchini yellow mosaic virus (ZYMV) was first reported in Italy and France by Lisa et al. (32) and became a major pathogen in cucurbits worldwide within a few years $(1,11,30,38)$.

Various strains of ZYMV have been described that differ in biological functions such as symptoms on different hosts and efficiency of transmission by aphids $(1,12,29,30,38,47)$. A mild strain of ZYMV, designated weak (ZYMV-WK), has been characterized (12, $29)$. This variant strain was isolated from the poorly aphid-transmitted isolate E15-PAT (29) and was found to successfully protect against several virulent strains of ZYMV in field experiments at different locations $(29,36,43,46)$. Sequence comparison between the helper component-protease (HC-Pro) of the severe strain ZYMVNAT $(6,16)$ and the mild strain ZYMV-WK showed three amino acid changes (23). One of the mutations (Thr to Ala) at the conserved motif Phe-Thr-Lys (PTK) greatly diminished the aphid transmissibility of ZYMV-WK (23).

The HC-Pro is the second gene product processed from the potyvirus polyprotein by cis cleavage of the $\mathrm{P} 1$ protein at the amino terminus $(39,45)$ and by autocatalytic protease activity at the carboxy terminus (7). The protein has been extensively studied as a multifunctional protein (33). The HC-Pro mediates aphid transmission (37), exhibits viral cis protease activity (7), maintains virus replication $(24,26)$, stimulates long-distance virus transport $(8,40)$, enhances replication of an RNA virus that elicits a synergistic disease (42), and most recently, has been found to suppress virus-induced gene silencing (25). The HC-Pro protein has also been shown to be associated with an alteration of symptom expression $(2,3,8$, 13,27). Atreya et al. (2) showed that a single change in the $\mathrm{N}^{\prime}$ terminus of Tobacco vein mottling virus (TVMV) The HC-Pro affected virus accumulation and symptom expression. Replacement of twothirds of the HC-Pro gene from TVMV with the analogous gene

Corresponding author: A. Gal-On; E-mail address: zymv@ netvision.net.il

Publication no. P-2000-0309-01R

(C) 2000 The American Phytopathological Society portion from ZYMV within a TVMV infectious clone caused attenuation of symptoms on Nicotiana benthamiana and reduced virus accumulation (3). Several mutations that were introduced into the HC-Pro decreased virus accumulation and symptom expression (8). These results imply the possibility of interaction or modulation of the HC-Pro protein with host components.

In the current study, we demonstrate for the first time a unique amino acid change within the conserved potyvirus motif (FRNK) that dramatically reduced symptom expression in cucurbits without affecting virus accumulation and elicited protection against severe ZYMV strains.

\section{MATERIALS AND METHODS}

Construction of the mutants in the full-length clone (FLC) of ZYMV. The previously cloned HC-Pro gene of ZYMV-WK, designated pZYHC(-) (23), was used as a template for exchange of fragments BstXI/BstEII and BstXI/BamHI (Figs. 1 and 2). These fragments were inserted in the appropriate sites in the FLC of 35SZYMVNATNOS (Fig. 1A) (17). Site-directed mutagenesis was introduced by the Kunkel procedure (28) on the single-stranded DNA template of the subclone pksM16B (15) using the AG primer 5'-ATGTTCATAAATAagcgetCTAG-3'. The AG primer harbors the sequence of the new amino acid Ile (ATA underlined), as well as the changed nucleotide $\mathrm{c}$ ( $\mathrm{c}$ underlined), to generate the unique restriction site of Eco47III (agcgct). The clone pKSM16B carrying the mutations was double-digested by BamHI/BstEII, and the resulting fragment $(1.4 \mathrm{~kb})$ was introduced between the same site in the 35SZYMVNOS cDNA (18). This clone was infectious and the progeny virus was designated ZYMV-AG.

Plants, virus strain, and inoculation. Greenhouse-grown zucchini squash (Cucurbita pepo L. cv. Ma'ayan), cucumber ( $\mathrm{Cu}$ cumis sativus L. cvs. Beit Alpha, Shimshon, and Delila), melon (Cucumis melo L. cv. Arava), and watermelon (Citrullus lanatus (Thunb.) Matsum. \& Nakai cv. Malali) plants were inoculated at the cotyledon stage. ZYMV-AT (a local aphid-transmissible strain), 
ZYMV-NAT (an aphid-nontransmissible strain) (15), ZYMV-WK mild strain (poorly aphid transmissible) (29), and ZYMV-CA (California strain) (22) were used in this study. The inoculated plants were maintained in a growth chamber under continuous light at about $25^{\circ} \mathrm{C}$ and were visually examined daily for symptom development. Mechanical inoculations were performed by applying sap extracts (about $1 \mathrm{~g}$ of leaves per $\mathrm{ml}$ of water) to a cotyledon that had previously been dusted with Carborundum. Bombardment inoculations were performed as previously described by Gal-On et al. $(17,18)$. Infected squash plants served as the source for acquisition access by the green peach aphids Myzus persicae. Aphids fasted for $1 \mathrm{~h}$ and were then allowed a 5-min acquisition access period, followed by an 18-h inoculation access period on squash and cucumber seedlings.

Determination of the mutant ZYMV-AG in the progeny virions. To ascertain the presence of the mutation in the viral RNA, total mRNA from infected leaf tissue was extracted according to Dellaporta et al. (9). Reverse-transcription-polymerase chain reaction (RT-PCR) was performed as described by Huet et al. (23), with antisense primer 5'-CAGCTGCTCCTCGAGTTTAATG-3' at position 2,438 and sense primer 5'-GTGATTCGAGGTAGAGACGACG-3' at position 991 (numbered from the $5^{\prime}$ end of the ZYMV genome). The predicted amplified fragment $(1.4 \mathrm{~kb})$ was column purified with the High Pure PCR product purification kit (Boehringer Mannheim, Mannheim, Germany) and digested by Eco47III for verification.

Cross-protection experiments. Cross protection was tested as described by Lecoq et al. (29). Squash seedlings (81 plants) at the fully expanded cotyledon stage were bombarded with the $35 \mathrm{~S}-\mathrm{AG}$ cDNA at a rate of $0.1 \mu \mathrm{g} / \mu \mathrm{l}$ (in the greenhouse) or sap inoculated with ZYMV-AG (in the field). At 10 days postinfection, plants were challenge inoculated with ZYMV-AT using five to seven aphids (Myzus persicae) per plant (1), sap inoculated with ZYMV strains NAT or CA, or both challenge and sap inoculated. Protection was evaluated by visual observation of leaf and fruit symptoms.

Enzyme-linked immunosorbent assay (ELISA) for evaluation of the ZYMV titer. Four leaf disks per plant of ZYMV-infected squash and cucumber plants were taken 7 to 18 days postinocula- tion (dpi) from different noninoculated leaves and the homogenized tissue samples were subjected to ELISA, as described by Antignus et al. (1).

\section{RESULTS}

Analysis of the HC-Pro sequence responsible for symptom expression. Sequence analyses of the HC-Pro genes of the WK and NAT strains revealed three amino acid differences in conserved motifs (Fig. 1B and C) (23). To examine the involvement of those amino acids in symptom development, sequence fragments containing these encoded amino acid differences were cloned into the respective positions within the infectious ZYMV cDNA 35SZYMVNATNOS (Fig. 2A) (15). Exchanging the BstXI/BamHI fragment from the HC-Pro of ZYMV-WK within p35SZYMVNATNOS did not affect symptom expression (Fig. 2B). However, replacement of the BstEII/BstXI fragment altered symptom expression of the hybrid virus in cucurbits (Fig. 2C). To distinguish which of the two variant amino acids (Asp 148 or Arg 180) located in the BstEII/BstXI fragment (Fig. 2C) affects symptom development, Arg 180 was replaced with Ile within the FRNK box by site-directed mutagenesis (Fig. 2, clone E). The resulting hybrid virus, harboring the amino acid Ile at position 180 within the HC-Pro, was designated ZYMV-AG.

Characterization of symptom expression of the engineered virus ZYMV-AG. The ZYMV-AG mutant did not cause the development of symptoms in three different cucumber genotypes (cvs. Beit Alpha, Delila, and Kfir) (Fig. 3), melon, and watermelon. Mild symptoms were induced by the ZYMV-AG mutant in squash similar to those induced by ZYMV-WK. The symptoms in squash comprised a mild green mosaic, especially in younger leaves, but no fruit deformation was observed. Mild symptoms were expressed in two different genotypes of squash (cvs. Ma'ayan and Erlika) (data not shown), which suggests a non-genotype-specific phenomenon. In contrast, alteration of Asp to Gly at position 148 in the infectious clone (Fig. 2D) caused severe symptoms. The symptoms were similar to those produced by the parental ZYMV-NAT, which means that this mutation was not involved in symptom expression.

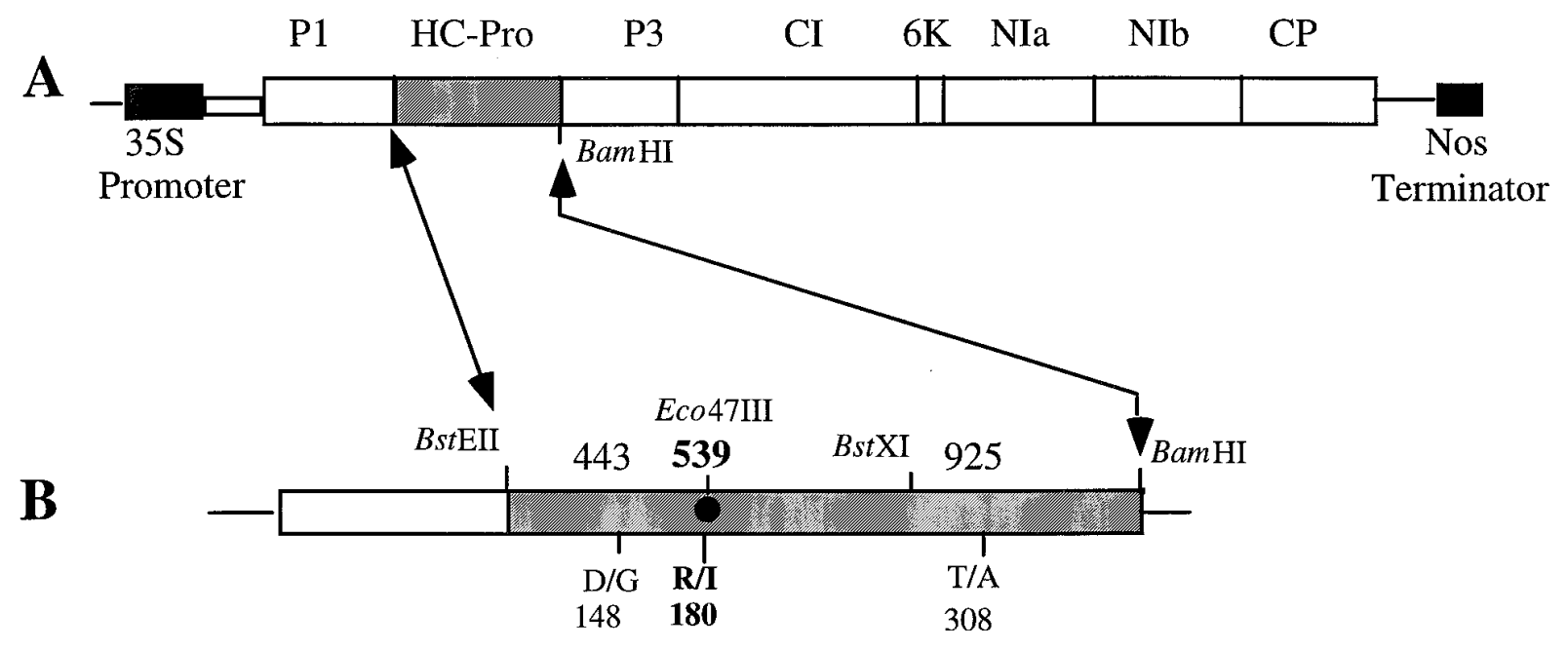

C

$\begin{array}{llll}\text { ZYMV-NAT } & 148 \mathrm{D} \mathrm{E} & 179 \mathrm{FRN} \mathrm{K} & 308 \text { P T K } \\ \text { ZYMV-WK } & 148 \mathrm{GE} & 179 \text { FIDN K } & 308 \text { P A K }\end{array}$

Fig. 1. Amino acid differences between Zucchini yellow mosaic virus (ZYMV)-NAT and ZYMV-WK within the helper component-protease (HC-Pro) gene. A, Schematic drawing of the hybrid full-length clone of ZYMV used for bombardment inoculation. The striped bar marks the mild ZYMV-WK sequence. B, Subclone of BstEII/BamHI fragment of ZYMV-WK into the ZYMV-NAT clone. The location of the nucleotide and the amino acid differences between the HC-Pro of the WK and NAT strains are marked: numbers above (nucleotides) and below (amino acids) the bar designate the WK sequence. The relevant restriction enzyme sites are indicated. C, Sequence comparison of the conserved regions in the HC-Pro that were found to differ between the two strains. An open circle indicates the mutation Ile that alters symptom expression. 
The HC-Pro gene of the progeny virus ZYMV-AG was cloned by RT-PCR and sequenced. The sequence of the HC-Pro gene of ZYMV-AG was identical to that of the ZYMV-NAT sequence, except for the single amino acid change (Ile) within the FRNK motif.

Accumulation and stability of the engineered virus ZYMVAG. Attenuated expression of virus symptoms could have been due to a low level of virus replication per cell or to restriction of virus movement. Therefore, accumulation of ZYMV-AG was detected by western blot and measured by ELISA, following inoculation. ZYMV-AG was detected 4 dpi and accumulated to a level similar to that of the wild-type ZYMV-AT at 6 and 10 dpi (Fig. 4). Sampling tissues $14 \mathrm{dpi}$ is not accurate due to the severely deformed leaves. The accumulation of the ZYMV-AG virus in systemically infected leaves was similar to the level of the attenuated wild-type ZYMV-WK and of the severe ZYMV-AT virus. The differences in virus accumulation in five independent experiments between the AG, AT, and WK isolates were not significant after 7 $(P>0.15)$ and $10 \mathrm{dpi}(P>0.2)$ (Table 1$)$. The relatively low level of ZYMV-AT in experiment 6 (0.3 optical density; Table 1) was because the infected leaves were sampled $18 \mathrm{dpi}$, at which stage symptoms of ZYMV-AT were very severe and the virus titer had dropped significantly.

The stability of the amino acid substitution of Arg for Ile at position 180 in ZYMV-AG was confirmed by visual observation of symptom expression in hundreds of infected squash plants. No symptoms were observed in most of the cucumber, watermelon, and melon plants (Table 2). After mechanical inoculation (by sap inoculation or particle bombardment) with ZYMV-AG, squash plants displayed mild symptoms, and cucumber and melon were symptomless for a period of 1.5 months (Table 2). In parallel to the visual observations, approximately $7.5 \%$ of the inoculated plants were chosen to determine the presence of the Ile mutation; all were found to be positive (Table 2). The viral RNA was amplified by RT-PCR, and the fragments obtained were verified directly by sequencing or indirectly by digestion with the restriction enzyme Eco47III (a unique Eco47III site was engineered into the AG strain) (Fig. 1). The two fragments obtained after Eco47III digestion in lane 2 (AG Cut) distinguished ZYMV-AG from ZYMV-NAT in lane 4 (Fig. 5). Five plants from each cultivar were kept for a period of 2 months, and the mild symptoms remained unchanged (data not shown). In addition, five passages of inoculum from plant to plant in squash were performed (3 weeks between each passage); the mild symptoms remained unchanged and no molecular reversion appeared (data not shown).

The attenuated ZYMV-AG strain protects against severe ZYMV strains. The ability of the newly produced mild ZYMVAG to protect against a challenge inoculation by the severe strain ZYMV-AT was studied in cross-protection experiments with squash plants in a greenhouse (Table 3). Nearly all of the protected plants displayed mild symptoms after a challenge with the severe strain ZYMV-AT (96\% protection). Two plants out of 62 that were infected with the AG strain and challenged with the severe AT strain exhibited severe symptoms 1 month postinoculation (Table 3). The cross protection was also tested in a small field experiment, with

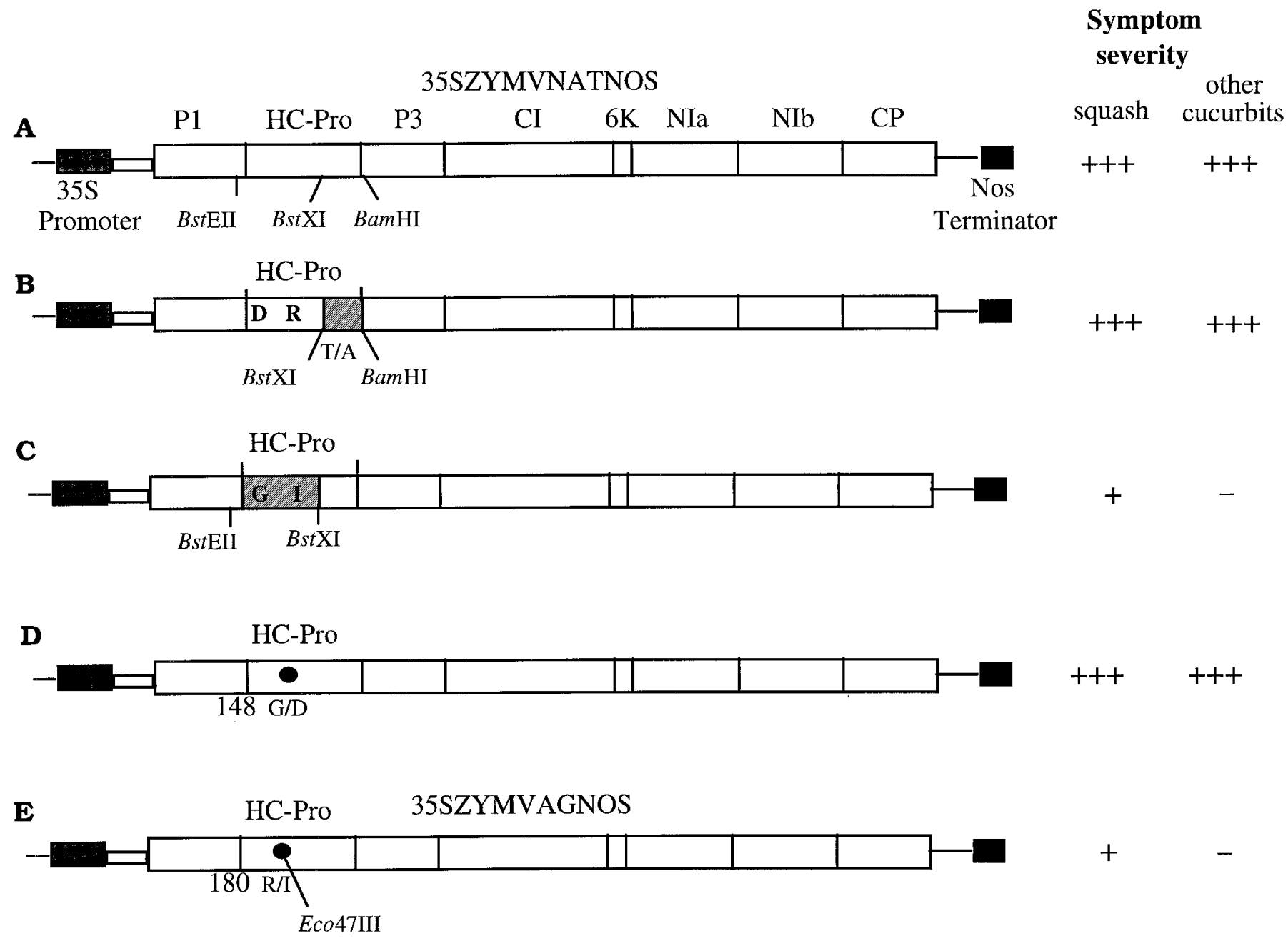

Fig. 2. A to E, Schematic drawing of five constructs of Zucchini yellow mosaic virus (ZYMV) infectious cDNA. The open and striped bars indicate the ZYMVNAT and ZYMV-WK sequences, respectively, within the full-length clone (FLC). The relevant restriction enzyme sites and amino acid changes are indicated. On the right-hand side, the severity of symptom expression is indicated, ranging from very severe (+++) to mild (+) in squash or to symptomless $(-)$ in other cucurbits (cucumber, melon, and watermelon). 
the protected squash plants exposed to natural aphid-transmission inoculation. None of the plants protected with ZYMV-AG showed severe symptoms and no fruit damage was observed, while approximately $40 \%(7 / 18)$ of the control nonprotected plants became infected (Table 3).

In addition, plants inoculated with ZYMV-AG were protected against mechanical challenge by two additional severe ZYMV isolates: ZYMV-NAT (15) and ZYMV-CA (48) (data not shown).

\section{DISCUSSION}

Three amino acid differences between the wild-type mild strain ZYMV-WK and the severe strain ZYMV-AT were found in conserved motifs within the HC-Pro gene (Table 4, lines 2 and 3). The substitution of Asp to Gly at position 148 was found in this study to have a negligible effect on symptom expression (Fig. 2D) and was present in two ZYMV strains, WK and E15-PAT $(21,30)$ (Table 4, lines 2 and 6). Both strains were transmitted inefficiently by aphids, but only the WK strain expressed mild symptoms (20, 30), which indicates that the Asp for Gly substitution had no effect on symptom expression.

The substitution within the PTK motif (Table 4, lines 2 and 6) had previously been demonstrated to be associated with aphid transmission $(23,35)$. The amino acid change in the FRNK motif (from Arg to Ile) appears only in ZYMV-WK, implying possible association with symptom expression. In this study, substitution of Arg for Ile within ZYMV-NAT (16) generated a virus that dramatically reduced symptom expression and fruit damage in cucurbits, although accumulation of the virus reached a level similar to that of the wild type.

The sequence FRNK is a conserved motif in 18 different potyviruses and in many different isolates of those viruses (Table 5; data from GenBank). There are two exceptions: in Johnsongrass mosaic virus (JGMV), in which phenylalanine and arginine are replaced by tyrosine and lysine, and in ZYMV-WK, in which arginine is replaced by isoleucine. However, in the case of JGMV,

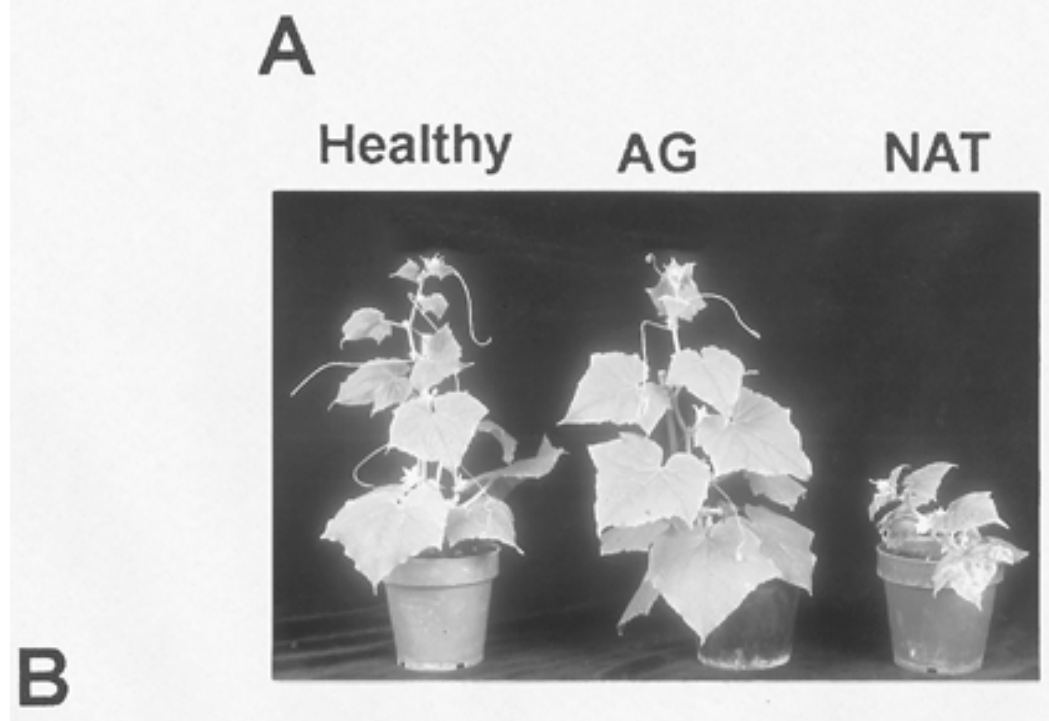

ZVMV-AG
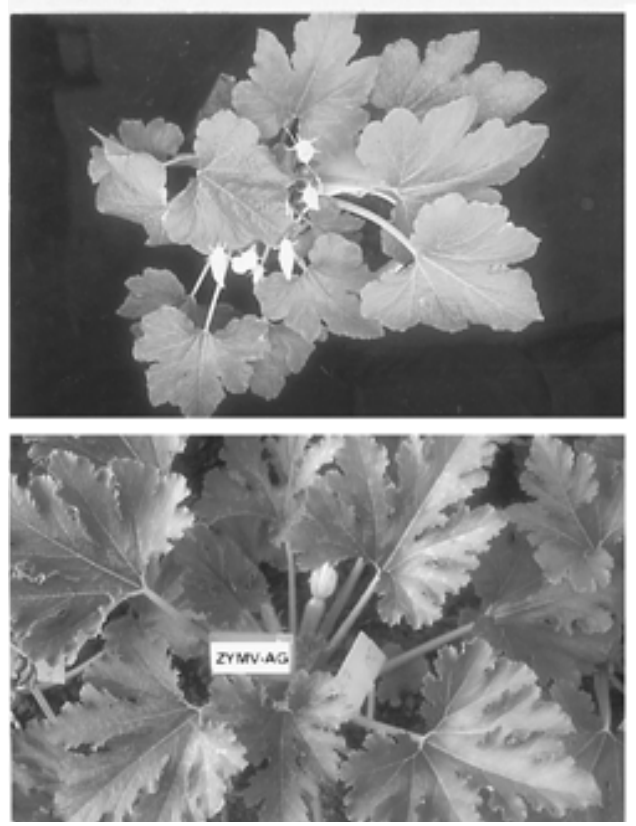

ZVMV-NAT
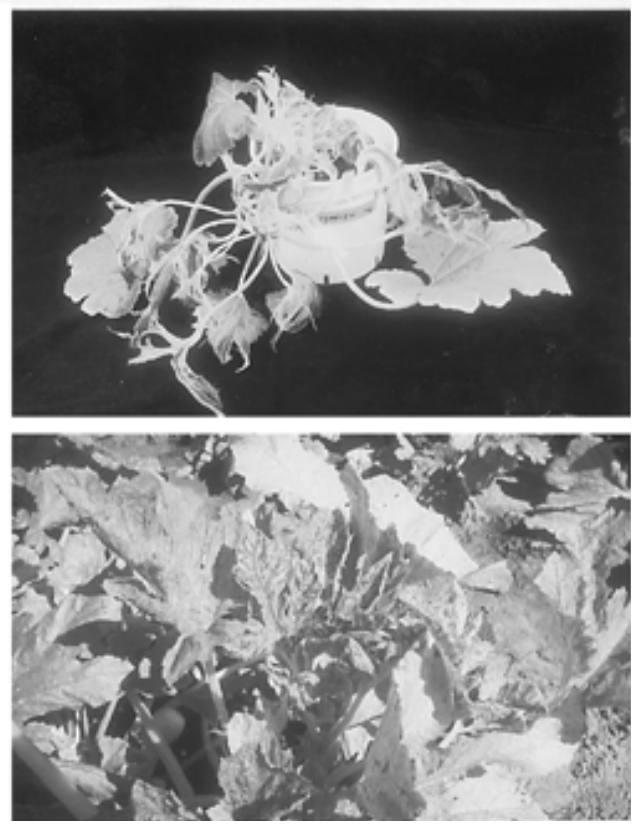

Fig. 3. A, Symptom expression of cucumber plants infected with the wild-type severe strain Zucchini yellow mosaic virus (ZYMV)-NAT (right), the mild mutant virus ZYMV-AG (middle), and mock inoculated (left) 3 weeks postinoculation. B, Symptom expression of squash infected in the greenhouse (upper) and in the field (lower) with the wild-type severe strain ZYMV-NAT (right) and the mild mutant virus ZYMV-AG (left). 
symptom expression was severe (20; D. D. Shukla, personal communication), while in the case of ZYMV-WK, mild symptoms were expressed. It is interesting that the FRNK motif does not exist in Ryegrass mosaic virus and Wheat streak mosaic virus (44), both members of the genus Rymovirus of the family Potyviridae, which are transmitted by mites. The FRNK motif appears only in aphidtransmitted potyviruses, although the association of the FRNK motif with aphid transmission has not been demonstrated.

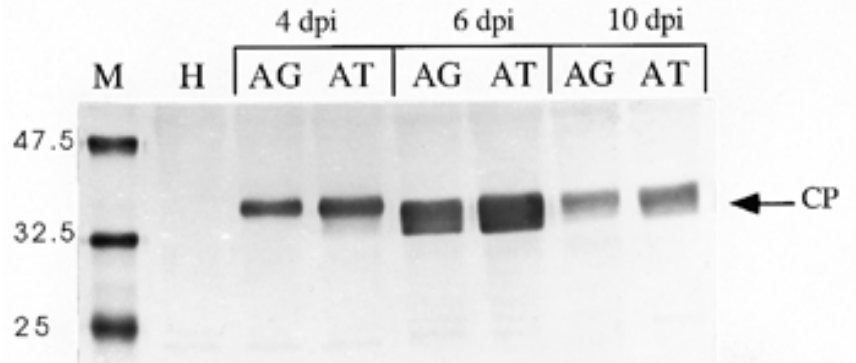

Fig. 4. Time course of Zucchini yellow mosaic virus (ZYMV) coat protein (CP) accumulation in squash seedlings sap inoculated with the cloned ZYMVAG and ZYMV-AT. Leaf disks were sampled 4, 6, and 10 days postinoculation from a systemically infected leaf. Proteins were separated on $12 \%$ polyacrylamide gels, transferred to nitrocellulose, and probed with anti-ZYMV $\mathrm{CP}$ antibodies. The $\mathrm{CP}(34 \mathrm{kDa})$ and the sizes of molecular weight markers (M) are indicated in kilodaltons.

TABLE 1. Comparison of virus accumulation between Zucchini yellow mosaic virus (ZYMV)-AG, ZYMV-AT, and ZYMV-WK strains in cucurbits at different days postinoculation (dpi)

\begin{tabular}{lrccc}
\hline & & \multicolumn{3}{c}{ Mean ELISA reading at optical density at $405 \mathrm{~nm}^{\mathrm{a}}$} \\
\cline { 3 - 5 } $\begin{array}{l}\text { Experiment } \\
\text { number }\end{array}$ & dpi & $\begin{array}{c}\text { ZYMV-AG } \\
\text { mild }\end{array}$ & $\begin{array}{c}\text { ZYMV-AT }^{\mathrm{c}} \\
\text { severe }\end{array}$ & $\begin{array}{c}\text { ZYMV-WK } \\
\text { mild }\end{array}$ \\
\hline $1 \mathrm{~s}^{\mathrm{e}}$ & 7 & 0.5 & 0.9 & 0.7 \\
$2 \mathrm{~s}$ & 7 & 0.7 & 1.0 & $\mathrm{NT}^{\mathrm{f}}$ \\
$3 \mathrm{~s}$ & 7 & 0.95 & 0.82 & $\mathrm{NT}$ \\
$4 \mathrm{~s}$ & 10 & 0.7 & 0.56 & $\mathrm{NT}$ \\
$5 \mathrm{~s}$ & 10 & 0.46 & 0.51 & 0.59 \\
$6 \mathrm{~s}$ & 18 & 0.9 & 0.3 & 1.33 \\
$7 \mathrm{c}$ & 10 & 0.81 & 0.7 & $\mathrm{NT}$ \\
\hline
\end{tabular}

a The differences in the accumulation of the ZYMV strains (AG, AT, and WK) were determined by analysis of variance statistical analysis of nine plants from each treatment. ELISA = enzyme-linked immunosorbent assay.

$\mathrm{b}$ The engineered virus of ZYMV.

${ }^{c}$ Severe aphid-transmissible strain of ZYMV found in Israel (1).

d ZYMV weak strain described by Lecoq and Pitrat (30).

e Test plants: $\mathrm{s}$ and $\mathrm{c}$ are squash and cucumber, respectively.

${ }^{\mathrm{f}} \mathrm{NT}=$ not tested.

TABLE 2. Stability of the genetically engineered, attenuated virus Zucchini yellow mosaic virus (ZYMV)-AG in cucurbits as determined by symptom and molecular analysis

\begin{tabular}{|c|c|c|c|c|}
\hline \multirow[b]{2}{*}{$\begin{array}{l}\text { Cucurbit } \\
\text { species }\end{array}$} & \multirow{2}{*}{$\begin{array}{c}\text { No. of plants } \\
\text { inoculated } \\
\text { with ZYMV-AG } \\
\text { cDNA }\end{array}$} & \multicolumn{2}{|c|}{$\begin{array}{l}\text { No. of infected plants and } \\
\text { symptom development }^{\mathrm{a}}\end{array}$} & \multirow{2}{*}{$\begin{array}{l}\text { No. of plants } \\
\text { tested for } \\
\text { existence of Ile } \\
\text { mutation }^{\text {b }}\end{array}$} \\
\hline & & $\begin{array}{c}\text { Mild or } \\
\text { symptomless }\end{array}$ & Severe & \\
\hline Squash & 402 & $398 \mathrm{~m}$ & 0 & $10 / 10$ \\
\hline Cucumber & 105 & $103 \mathrm{~s}$ & 0 & $15 / 15$ \\
\hline Watermelon & 72 & $65 \mathrm{~s}$ & 0 & $10 / 10$ \\
\hline Melon & 86 & $72 \mathrm{~s}$ & 0 & $13 / 13$ \\
\hline Total & 665 & 638 & 0 & $48 / 48$ \\
\hline
\end{tabular}

a Total of infected plants as detected by visual symptoms and by enzymelinked immunosorbent assay about 1.5 months postinoculation. $\mathrm{m}=$ Mild and $\mathrm{s}=$ symptomless. The differences between the total numbers of inoculated plants and numbers of infected plants reflect those plants that were not infected.

${ }^{b}$ The presence of the Ile mutation was confirmed by digestion of the reversetranscription-polymerase chain reaction products with Eco47III restriction enzyme or by sequencing. Number of plants are those tested/confirmed.
Association of the HC-Pro with severity of symptom expression has been demonstrated in potyviruses that infect tobacco $(2,3,8,27)$. Introducing changes within the HC-Pro of the potyviruses TVMV (5) and Tobacco etch virus (TEV) (13) led to attenuation of symptom expression, along with reduced virus accumulation. Klein et al. (27) introduced random mutations in the HC-Pro of TVMV to study gene function. Two mutants, HC-1937 and HC-1937?15, in a nonconserved region of the carboxy part of the $\mathrm{HC}$ altered symptoms from severe to mild, while the virus titer accumulated to relatively very low levels.

Cronin et al. (8) replaced the Phe-Arg-Asn (FRN) motif located within the FRNK in TEV with Arg-Pro-Ala (RPA). This artificial change caused a delay of symptom appearance and a lower virus accumulation compared with the wild type. The deletion used by Cronin et al. (8) also caused an alteration of symptom expression to mild, but this could be due to the low virus titer. In all of the above examples, alteration of symptom expression from severe to mild or symptomless was accompanied by reduced virus accumu-
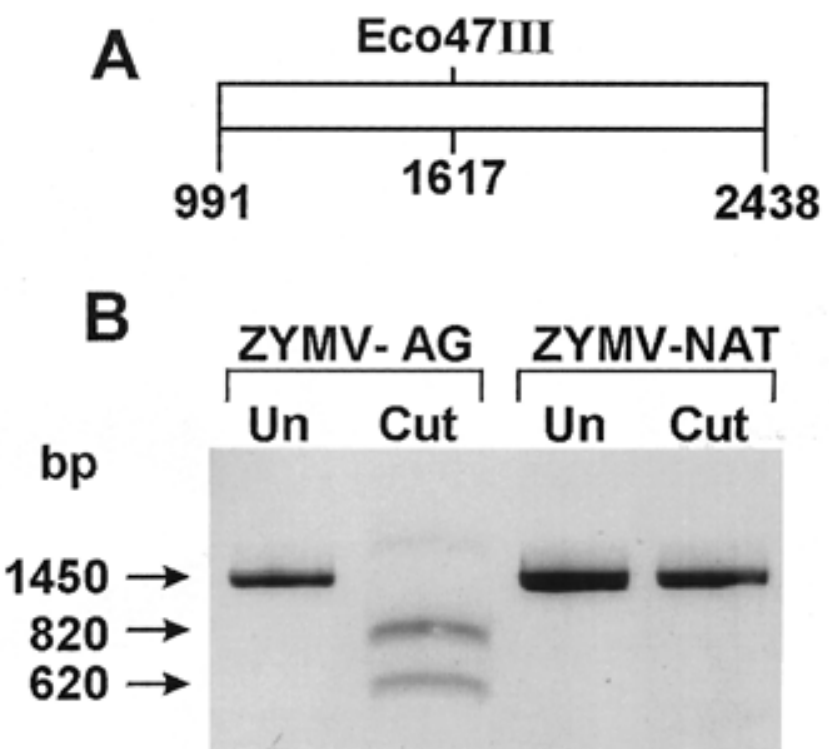

Fig. 5. Verification of the presence of hybrid Zucchini yellow mosaic virus (ZYMV)-AG virions by restriction analysis. A, Schematic drawing of the helper component-protease-amplified region (numbered from the $5^{\prime}$ end of the ZYMV sequence). B, The cDNA obtained by reverse-transcription-polymerase chain reaction from the total RNA of squash plants infected with ZYMV-AG and ZYMV-NAT (Un) were digested by Eco47III (Cut) to confirm the presence of the ZYMV-AG hybrid virus (negative of an ethidium bromide-stained gel). The relevant size (base pairs) of the cDNA fragments are indicated on the left.

TABLE 3. Cross protection in squash by Zucchini yellow mosaic virus (ZYMV)-AG against the severe strain ZYMV-AT in the greenhouse and field

\begin{tabular}{|c|c|c|c|c|c|}
\hline \multirow[b]{3}{*}{ Experiment } & \multicolumn{5}{|c|}{ Number of tested plants } \\
\hline & \multirow{2}{*}{$\begin{array}{l}\text { Mechanically } \\
\text { inoculated }^{\mathrm{a}}\end{array}$} & \multirow{2}{*}{$\begin{array}{l}\text { Challenge } \\
\text { inoculated }^{\mathrm{b}}\end{array}$} & \multicolumn{2}{|c|}{ Symptoms ${ }^{\mathrm{c}}$} & \multirow{2}{*}{$\begin{array}{c}\text { Showing fruit } \\
\text { damage }\end{array}$} \\
\hline & & & Mild & Severe & \\
\hline \multirow[t]{3}{*}{ Greenhouse } & 62 & 62 & 60 & 2 & 1 \\
\hline & 19 & 0 & 19 & 0 & 0 \\
\hline & 0 & 10 & 0 & 10 & 10 \\
\hline \multirow[t]{3}{*}{ Field } & 43 & 43 & 43 & 0 & 0 \\
\hline & 0 & 6 & 0 & 6 & 6 \\
\hline & 0 & (18) & 0 & 7 & 7 \\
\hline
\end{tabular}

a Mechanically inoculated with ZYMV-AG.

${ }^{\mathrm{b}}$ In the greenhouse experiment, challenge inoculation was aphid inoculation with ZYMV-AT. In the field experiment, challenge inoculation was exposure to natural inoculation. In the field experiment, squash seedlings were inoculated with ZYMV-AG (43 plants) and ZYMV-AT (6 plants). Eighteen uninfected plants were placed in the field to examine the natural aphid-inoculation pressure.

${ }^{c}$ Symptoms (mild and severe) were determined visually for every plant. 
lation. However, in ZYMV-AG, the virus accumulated to a level similar to that of the wild type.

We have shown in the current study that the replacement of a basic amino acid (Arg) with a hydrophobic amino acid (Ile) in the FRNK motif dramatically affected virus symptom expression but did not affect virus accumulation. Therefore, it might be that this protein motif interacts with a host factor (as a receptor) or viral protein, which induces disease symptoms. The Arg, Asn, and Lys in the FRNK motif are charged polar amino acids; therefore, the replacement of the basic Arg with the hydrophobic amino acid Ile drastically changed the polarity of the motif, which may have affected the interaction with a putative host factor.

It is notable that the change of one amino acid in the multifunctional HC-Pro affected only symptom expression. The mutation, therefore, does not affect the functions of the entire protein, but only a specific putative protein-protein interaction. Similarly, the change in the aphid transmissibility motif from DAG to DTG at the amino terminus of the coat protein $(\mathrm{CP})$ of potyviruses $(4,16)$ does not affect other CP functions. To date, no interactions of the HC-Pro with plant factors have been identified. However, host interactions have been observed with two Turnip mosaic virus potyvirus gene products: (i) VPg (genome-linked virion protein) with

TABLE 4. Comparison of amino acid sequences in conserved motifs of the helper component-protease gene of different Zucchini yellow mosaic virus (ZYMV) isolates

\begin{tabular}{|c|c|c|c|c|}
\hline \multirow[b]{2}{*}{ ZYMV strains } & \multicolumn{3}{|c|}{ Sequence at position } & \multirow{2}{*}{$\begin{array}{c}\text { Reference } \\
\text { (GenBank accession no.) }\end{array}$} \\
\hline & 148 & 179 & 308 & \\
\hline ZYMV-AGa & $\mathrm{DE}$ & FINK & PTK & Genetically engineered virus \\
\hline ZYMV-WK ${ }^{\mathrm{b}}$ & GE & FINK & PAK & $23(X 77756)$ \\
\hline ZYMV-AT & $\mathrm{DE}$ & FRNK & PTK & 16 \\
\hline ZYMV-Cal & $\mathrm{DE}$ & FRNK & PTK & 6 \\
\hline ZYMV-E15-AT & $\mathrm{DE}$ & FRNK & PTK & 21 \\
\hline ZYMV-E15-PAT & GE & FRNK & PAK & $21(\mathrm{Z} 22759)$ \\
\hline ZYMV-R5A-PAT & $\mathrm{DE}$ & FRNK & PTK & 5 \\
\hline ZYMV-Reu & $\mathrm{DE}$ & FRNK & PTK & 47 (L29569) \\
\hline ZYMV-CA & $\mathrm{DE}$ & FRNK & PTK & 47 (L31350) \\
\hline ZYMV-S & $\mathrm{DE}$ & FRNK & PTK & 31 (AF014811) \\
\hline ZYMV-FL/AT & $\mathrm{DE}$ & FRNK & PTK & 47 (L35590) \\
\hline
\end{tabular}

a The amino acid change within the genetically engineered virus is indicted by the bold/underlined "I."

b The amino acid differences in the conserved motifs are indicated by the bold "G," "I," and "A."

TABLE 5. The helper component-protease of 18 potyviruses (genus Potyvirus) (44) harboring the FRNK motif, and their GenBank accession numbers

\begin{tabular}{ll}
\hline Potyvirus & \multicolumn{1}{c}{ Accession numbers } \\
\hline Bean yellow mosaic virus & $\mathrm{D} 83749, \mathrm{U} 47033, \mathrm{U} 19287$ \\
Clover yellow vein virus & $\mathrm{AB} 011819$ \\
Lettuce mosaic virus strains E and O & $\mathrm{X} 97705, \mathrm{X} 97704$ \\
Maize dwarf mosaic virus & $\mathrm{AJ} 001691$ \\
Papaya ringspot virus & $\mathrm{X} 67673, \mathrm{X} 97251, \mathrm{~S} 46722, \mathrm{X} 96537$, \\
& $\mathrm{X} 16415$ \\
Pea seed-borne mosaic virus & $\mathrm{D} 10930, \mathrm{D} 01152, \mathrm{X} 89997$ \\
Peanut mottle virus & $\mathrm{AF} 023848, \mathrm{U} 05771$ \\
Pepper mottle virus & $\mathrm{M} 96425$ \\
Plum pox virus strain M & $\mathrm{AJ} 243957, \mathrm{D} 13751$ \\
Potato virus A & $\mathrm{Y} 14860, \mathrm{Y} 14128, \mathrm{Y} 14127, \mathrm{Y} 14126$, \\
& $\mathrm{Y} 14125, \mathrm{Y} 14124, \mathrm{Y} 14123, \mathrm{Y} 14122$, \\
Potato virus $Y$ & $\mathrm{U} 33454, \mathrm{X} 97895, \mathrm{D} 00441, \mathrm{Z} 50043$, \\
& $\mathrm{Z} 50042, \mathrm{M} 95491, \mathrm{Z} 50041$, \\
Soybean mosaic virus & $\mathrm{M} 37180, \mathrm{M} 38377, \mathrm{M} 37146$ \\
Sweet potato feathery mottle virus & $\mathrm{D} 86371$ \\
Tobacco etch virus & $\mathrm{L} 38714$ \\
Tobacco vein mottling virus & $\mathrm{X} 04083, \mathrm{~K} 02991$ \\
Turnip mosaic virus & $\mathrm{D} 10927$ \\
Yam mosaic virus & $\mathrm{U} 42596$ \\
Zucchini yellow mosaic virus & AF014811, Z22759, L35590, L31350, \\
& $\mathrm{L} 29569$ \\
\hline
\end{tabular}

host factor eIF(iso)4E (48), and (ii) CP with a 37-kDa host protein (34). The unique aspect of the current study is that this is the first evidence that a natural point mutation in the potyvirus HC-Pro dramatically changes symptom expression.

Although mutations within RNA viruses are frequent (14,31), the engineered attenuated ZYMV-AG induced mild mosaic symptoms for long growing periods and after several passages. Similar results with a stable point mutation were obtained with a genetically engineered non-aphid-transmissible isolate (ZYMV-NAT) within the DTG motif in the CP (16) or within the PTK motif in the HCPro (23). The stability of the ZYMV-AG could perhaps be explained by the fact that the single amino acid change was not the result of a random mutation, but was introduced from a wild-type sequence, ZYMV-WK, that had been selected through evolution.

The current paper is the first report of cross protection taking place between strains that have almost identical sequences (ZYMVAT and ZYMV-AG). The resistance-breaking virus that appeared in two plants did so at a relatively late stage (1.5 months postinoculation). A low level of resistance breaking had also been found in field experiments with the native ZYMV-WK and was explained as resulting from high inoculum levels (47).

Previous studies have shown that in typical cross protection both the protective and the challenge virus strains are very closely related $(19,41)$. Desbiez et al. (10) used monoclonal antibodies to demonstrate that the protecting ZYMV strain prevents the establishment of the challenge strain in the plant. The system of severe and attenuated cloned ZYMV strains permits the study of the cross-protection phenomenon with better tools than was previously available.

\section{ACKNOWLEDGMENTS}

This research was supported, in part, by grants from the U.S.-Israel Binational Research and Development Fund (US-2541-95R) and the Chief Scientist of the Ministry of Agriculture (136-0302-97). Contribution no. 507/99 series from the Agricultural Research Organization, the Volcani Center, Bet Dagan, Israel. I thank V. Gaba for comments on the manuscript prior to submission and for reviewing and editing the manuscript.

\section{LITERATURE CITED}

1. Antignus, Y., Raccah, B., Gal-On, A., and Cohen, S. 1989. Biological and serological characterization of zucchini yellow mosaic virus and watermelon mosaic virus-2 isolates in Israel. Phytoparasitica 17:289-298.

2. Atreya, C. D., Atreya, P. L., Thornbury, D. W., and Pirone, T. P. 1992. Site-directed mutations in the potyvirus HC-Pro gene affect helper component activity, virus accumulation, and symptom expression in infected tobacco plants. Virology 191:106-111.

3. Atreya, C. D., and Pirone, T. P. 1993. Mutational analysis of the helper component-proteinase gene of a potyvirus: Effects of amino acid substitutions, deletions, and gene replacement on virulence and aphid transmissibility. Proc. Natl. Acad. Sci. U.S.A. 90:11919-11923.

4. Atreya, C. D., Raccah, B., and Pirone, T. P. 1990. A point mutation in the coat protein abolishes aphid transmissibility of a potyvirus. Virology 178:161-165.

5. Baker, C. A., Hiebert, E., Marlow, G. C., and Wisler, G. C. 1992. Comparative sequence analysis of the Reunion isolate of zucchini yellow mosaic virus. (Abstr.) Phytopathology 82:1176.

6. Balint, R., Polooy, I., and Steele, C. 1990. The nucleotide sequence of zucchini yellow mosaic potyvirus. (Abstr.) Int. Congr. Virol. 82:1176.

7. Carrington, J. C., Cary, S. M., Parks, T. D., and Dougherty, W. G. 1989. A second proteinase encoded by a plant potyvirus genome. EMBO (Eur. Mol. Biol. Organ.) J. 8:365-370.

8. Cronin, S., Verchot, J., Haldeman, C. R., Schaad, M. C., and Carrington, J. C. 1995. Long-distance movement factor: A transport function of the potyvirus helper component proteinase. Plant Cell 7:549-559.

9. Dellaporta, S. L., Wood, J., and Hicks, J. B. 1983. A plant DNA minipreparation revision II. Plant Mol. Biol. Rep. 1:19-21.

10. Desbiez, C., Gal-On, A., Raccah, B., and Lecoq, H. 1997. Characterization of epitopes on zucchini yellow mosaic potyvirus coat protein permits studies on the interactions between strains. J. Gen. Virol. 78:2073-2076.

11. Desbiez, C., and Lecoq, H. 1997. Zucchini yellow mosaic virus. Plant Pathol. 46:809-829.

12. Desbiez, C., Wipf-Scheibel, C., Granier, F., Robaglia, C., Delaunay, T., and Lecoq, H. 1996. Biological and molecular variability of zucchini 
yellow mosaic virus on the island of Martinique. Plant Dis. 80:203-207.

13. Dolja, V. V., Herndon, K. L., Pirone, T. P., and Carrington, J. C. 1993. Spontaneous mutagenesis of a plant potyvirus genome after insertion of a foreign gene. J. Virol. 67:5968-5975.

14. Domingo, E., and Holland, J. J. 1997. RNA virus mutations and fitness for survival. Annu. Rev. Microbiol. 51:151-178.

15. Gal-On, A., Antignus, Y., Rosner, A., and Raccah, B. 1991. Infectious in vitro RNA transcripts derived from cloned cDNA of the cucurbit potyvirus, zucchini yellow mosaic virus. J. Gen. Virol. 72:2639-2643.

16. Gal-On, A., Antignus, Y., Rosner, A., and Raccah, B. 1992. A zucchini yellow mosaic virus coat protein gene mutation restores aphid transmissibility but has no effect on multiplication. J. Gen. Virol. 73:2183-2187.

17. Gal-On, A., Meiri, C., Elman, C., Gray, D. J., and Gaba, V. 1997. Simple hand-held devices for the efficient infection of plants with viral-encoding constructs by particle bombardment. J. Virol. Methods 64:103-110.

18. Gal-On, A., Meiri, E., Huet, H., Hua, W. J., Raccah, B., and Gaba, V. 1995. Particle bombardment drastically increases the infectivity of cloned DNA of zucchini yellow mosaic potyvirus. J. Gen. Virol. 76:3223-3227.

19. Gonsalves, D., and Garnsey, S. M. 1989. Cross-protection techniques for control of plant virus diseases in the tropics. Plant Dis. 73:592-597.

20. Gough, K. H., and Shukla, D. D. 1993. Nucleotide sequence of johnsongrass mosaic potyvirus genomic RNA. Intervirology 36:181-192.

21. Granier, F., Durand, T. M., Casse, D. F., Lecoq, H., and Robaglia, C. 1993. Mutations in zucchini yellow mosaic virus helper component protein associated with loss of aphid transmissibility. J. Gen. Virol. 74: 2737-2742.

22. Grumet, R., Bada, R., and Hammar, S. 1992. Analysis of the zucchini yellow mosaic virus (ZYMV) potyviral helper component, possible identification of an aphid-interaction domain. (Abstr.) Phytopathology 82:1176.

23. Huet, H., Gal-On, A., Meir, E., Lecoq, H., and Raccah, B. 1994. Mutations in the helper component protease gene of zucchini yellow mosaic virus affect its ability to mediate aphid transmissibility. J. Gen. Virol. 75: 1407-1414.

24. Kasschau, K. D., and Carrington, J. C. 1995. Requirement for HC-Pro processing during genome amplification of tobacco etch potyvirus. Virology 209:268-273.

25. Kasschau, K. D., and Carrington, J. C. 1998. A counterdefensive strategy of plant viruses: Suppression of posttranscriptional gene silencing. Cell 95:461-470.

26. Kasschau, K. D., Cronin, S., and Carrington, J. C. 1997. Genome amplification and long-distance movement functions associated with the central domain of tobacco etch potyvirus helper component-proteinase. Virology 228:251-262.

27. Klein, P. G., Klein, R. R., Rodriguez-Cerezo, E., Hunt, A. G., and Shaw, J. G. 1994. Mutational analysis of the tobacco vein mottling virus genome. Virology 204:759-769.

28. Kunkel, T. A. 1987. Rapid and efficient site-specific mutagenesis without phenotypic selection. Proc. Natl. Acad. Sci. U.S.A. 82:488-492.

29. Lecoq, H., Lemaire, J. M., and Wipf-Scheibel, C. 1991. Control of zucchini yellow mosaic virus in squash by cross protection. Plant Dis. 75: 208-211.

30. Lecoq, H., and Pitrat, M. 1984. Strains of zucchini yellow mosaic virus in muskmelon. Phytopathol. Z. 111:165-173.

31. Lee, K. C., and Wong, S. M. 1998. Variability of P1 protein of zucchini yellow mosaic virus for strain differentiation and phylogenetic analysis with other potyviruses. DNA Sequence 9:275-293.

32. Lisa, V., Boccardo, G., D’Agostino, G., Dellavalle, G., and d'Aquilio, M. 1981. Characterization of a potyvirus that causes zucchini yellow mosaic. Phytopathology 71:667-672.

33. Maia, I. G., Haenni, A. L., and Bernardi, F. 1996. Potyviral HC-Pro: A multifunctional protein. J. Gen. Virol. 77:1335-1341.

34. McClintock, K., Lamarre, A., Parsons, V., Laliberte, J. F., and Fortin, M. G. 1998. Identification of a $37 \mathrm{kDa}$ plant protein that interacts with the turnip mosaic potyvirus capsid protein using anti-idiotypic-antibodies. Plant Mol. Biol. 37:197-204.

35. Peng, Y. H., Kadoury, D., Gal-On, A., Huet, H., Wang, Y., and Raccah, B. 1998. Mutations in the HC-Pro gene of zucchini yellow mosaic potyvirus: Effects on aphid transmission and binding to purified virions. J. Gen. Virol. 79:897-904.

36. Perring, T. M., Farrar, C. A., Blua, M. J., Wang, H. L., and Gonsalves, D. 1995. Cross protection of cantaloupe with a mild strain of zucchini yellow mosaic virus: Effectiveness and application. Crop Prot. 14:601-606.

37. Pirone, T. P., and Blanc, S. 1996. Helper-dependent vector transmission of plant viruses. Annu. Rev. Phytopathol. 34:227-247.

38. Provvidenti, R., Gonsalves, D., and Humaydan, H. S. 1984. Occurrence of zucchini yellow mosaic virus in cucurbits from Connecticut, New York, Florida, and California. Plant Dis. 68:443-446.

39. Riechmann, J. L., Laín, S., and García, J. A. 1992. Highlights and prospects of potyvirus molecular biology. J. Gen. Virol. 73:1-16.

40. Rojas, M. R., Zerbini, F. M., Allison, R. F., Gilbertson, R. L., and Lucas, W. J. 1997. Capsid protein and helper component-proteinase function as potyvirus cell-to-cell movement proteins. Virology 237:283-295.

41. Sherwood, J. L. 1987. Mechanisms of cross-protection between plant virus strains. Pages 136-150 in: Plant Resistance to Viruses. D. Evered and S. Harnett, eds. John Wiley and Sons, Chichester, England.

42. Shi, X. M., Miller, H., Verchot, J., Carrington, J. C., and Vance, V. B. 1997. Mutations in the region encoding the central domain of helper component-proteinase (HC-Pro) eliminate potato virus X/potyviral synergism. Virology 231:35-42.

43. Spence, N. J., Mead, A., Miller, A., Shaw, E. D., and Walkey, D. G. A. 1996. The effect on yield in courgette and marrow of the mild strain of zucchini yellow mosaic virus used for cross-protection. Ann. Appl. Biol. 129:247-259.

44. Stenger, D. C., Hall, J. S., Choi, I.-R., and French, R. 1998. Phylogenetic relationships within the family Potyviridae: Wheat streak mosaic virus and brome streak mosaic virus are not members of the genus Rymovirus. Phytopathology 88:782-787.

45. Verchot, J., Koonin, E. V., and Carrington, J. C. 1991. The 35-kDa protein from the N-terminus of the potyviral polyprotein functions as a third virus-encoded proteinase. Virology 185:527-535.

46. Walkey, D. G. A., Lecoq, H., Collier, R., and Dobson, S. 1992. Studies in the control of zucchini yellow mosaic virus in courgettes by mild strain protection. Plant Pathol. 41:762-771.

47. Wisler, G. C., Purcifull, D. E., and Hiebert, E. 1995. Characterization of the $\mathrm{P} 1$ protein and coding region of the zucchini yellow mosaic virus. J. Gen. Virol. 76:37-45.

48. Wittmann, S., Chatel, H., Fortin, M. G., and Laliberte, J. F. 1997. Interaction of the viral protein genome linked of turnip mosaic potyvirus with the translational eukaryotic initiation factor (iso) 4E of Arabidopsis thaliana using the yeast two-hybrid system. Virology 234:84-92.

\section{Erratum}

Vol. 90, No. 5, 2000

In the manuscript entitled "A Point Mutation in the FRNK Motif of the Potyvirus HC-Pro Gene Alters the Symptom Expression in Cucurbits and Exhibits Protection Against Severe Homologous Virus" that appeared in Phytopathology Vol. 90, pages 467-473, the authors should be A. Gal-On and B. Raccah, from the Department of Virology, The Volcani Center, Agricultural Research Organization. 